Trivent Publishing

(C) The Authors, 2016

Available online at http://trivent-publishing.eu/

Engineering and Industry Series

Volume Power Systems, Energy Markets and Renewable Energy Sources in

South-Eastern Europe

\title{
Energy Savings in Municipal Road Lighting: The Case of the Municipality of Hersonissos
}

\author{
Sofia Yfanti, ${ }^{1}$ Nikos Sakkas, ${ }^{2}$ Anastasia Nistikaki ${ }^{3}$ \\ ${ }^{1}$ Municipality of Hersonisos, Technical Service, Greece, s.ifanti@ hersonisos.gr \\ ${ }^{2}$ Department of Mechanical Engineer, Technological Educational \\ Institute of Crete, Greece \\ ${ }^{3}$ Municipality of Hersonisos, General Secretary, Greece,
}

\begin{abstract}
In an era governed by economic crisis, deep recession and lack of funds, the perspective of sustainable development drives local government to a more focused and constant effort to adapt to their daily requirements not only in respect to the central state but also towards the growing needs of the local society. Thereupon the vision of the Municipality of Hersonissos was the development, adoption and application of the basic principles of sustainable development. At the same time the Municipality's rigid vision, oriented by environmental protection, highlighted the need for networking on European level as although cities are different, their problems are often common. Thus on 2011, the Municipality joined the European Union initiative "Covenant of Mayors» [1] with the common aim of the fight against climate change. This article presents the initiatives taken in this direction in the past five years and their results. It also aims to point out a municipality's vital role in knowledge and technology diffusion within the local society as sustainable energy development can be deployed not only by the private sector but also by the public.
\end{abstract}

This is an Open Access article distributed in accordance with the Creative Commons Attribution Non Commercial (CC-BY-NC-ND 4.0) license, which permits others to copy or share the article, provided original work is properly cited and that this is not done for commercial purposes. Users may not remix, transform, or build upon the material and may not distribute the modified material (http://creativecommons.org/licenses/by-nc/4.0/)

DOI: $10.22618 /$ TP.EI.20163.389018 


\section{Keywords}

Sustainable energy development; Road lighting; Municipality; Crete; Greece

\section{Introduction}

Thissen et al. [2] stated that as regions compete in different products and geographical spaces, they are economically different from each other. They exhibit different strengths and weaknesses, and provide different possibilities for growth and development. Thus what fosters growth in one region may hamper it in another [2]. On the other hand, the Lisbon Strategy of the European Communities Commission [3] considers the advancing countries of Europe as the critical factors for making the European Union the most dynamic and competitive knowledge-based economy. Even though Greece is categorized as an advanced economy based on EBRD data [4], it has been harshly hit by the economic deflation since 2009, as a result of the world financial crisis. Based on Erawatch's 2011 country reports for Greece [5], the country's severe debt crisis in 2010 led to a bailout agreement with the IMF, the ECB and the European Commission, followed by a stringent austerity and consolidation program which in turn brought about cuts in public expenditures and investments. These cuts, together with projected tax increases and the persisting impact of the international financial crisis, led to a $3.5 \%$ decline of the GDP in 2010, and a further downturn of $6.8 \%$ in 2011 [6]. Taking in consideration the above, it is not strange for any region in the country to maximize its efforts for sustaining a high level of life for its citizens and therefore to search and approach all possible means or paths that could help the region awaken from the economic lethargy.

This article presents the significant effort of the Municipality of Hersonissos to remain a knowledge beacon and to regain its role in diffusing sustainable energy technology among its citizens and the companies that operate within its borders.

\section{The region}

Crete is a region of high significance for Greece as it is the biggest island of the country covering $6.3 \%$ of its total extent. Its population reached 621,340 residents in 2011 (see table 1), which was $5.8 \%$ of the total population of the country. The geographical distribution of the population between the prefectures, according to the most recent census shows that in Heraklion resides almost half of the region's population (48.9\%), followed by the prefecture of Chania (25.1\%). As expected, prefectures' capitals, along with some secondary urban centres such as Sitia and Ierapetra, constitute the main cities of the region. 
Table 1. Demographic Characteristics of Crete [7]

\begin{tabular}{|c|c|c|}
\hline & Crete & Greece \\
\hline Number of residents & 621,340 & $10,787,690$ \\
\hline $\begin{array}{c}\text { Population density } \\
\text { (residents/km2) }\end{array}$ & 74.54 & 81.75 \\
\hline
\end{tabular}

East from the city of Heraklion the Municipality of Hersonissos extends from the north coastline of central Crete to the imposing mountain chains of Lasithi. It is located a few kilometres away from Heraklion's international airport "Nikos Kazantzakis". Within its borders there are settlements with unique characteristics and colours which transform it to one of the most well-known travel destinations in Crete.

Within this framework the vision of the Municipality of Hersonissos, in relation to external and internal factors that are in their sphere of influence and as recorded in the Business Plan for 2011-2014, was its emergence in an Economic, Touristic and Cultural pole by adopting and applying the basic principles of sustainable development. In order for this objective to be achieved a pure vision, a strategic planning and an evaluation system oriented towards environmental protection was applied. For maximizing its effort the Municipality became a member of a broader network of organizations and municipalities that share the same visions at European level, acknowledging the fact that although cities are different, they have common problems.

\section{The Covenant of Mayors initiative}

In 2008 the European Union acknowledged the fact that in order for energy efficiency targets to be met, a widespread improvement in policy level was needed across European Regions. Thus a unique bottom up movement was set in motion with the support of the European Commission and hence the Covenant of Mayors for Climate and Energy was established.

On April 18, 2011, the Municipality of Hersonissos joined the European Union initiative "Covenant of Mayors» which is an ambitious incentive by the European Commission, which was established in order to mediate the climatic changes effects through the implementation of local sustainable energy policies [1]. Hence, it aims to unite its members against the battle for altering the conditions of the climate change. This network is a tool for achieving the EU goal 20-20-20, namely:

- Reducing energy consumption by at least $20 \%$

- Reducing the emission of greenhouse gases by $20 \%$.

- Introduction of $20 \%$ renewable energy. 
- with base year 1990 or the year closest to it with sufficient data and target year 2020. The Covenant of Mayors counts already 6,783 European city or region members (more than 125 in Greece) representing 211,266,931 European citizens [1]. These figures change on a daily basis as more and more organizations are willing to commit in energy consumption reduction.

With its integration in the Covenant of Mayors the Municipality of Hersonissos:

- Demonstrates strong political commitment to the movement against the climate change

- Promotes energy efficiency and a rational use of available natural resources

- Launches an Energy Task Manager till 2020

- Benefits from networking with other European cities by exchanging experience and know-how

- Benefits from the resource and finance savings that are created due to the adaptation of ecology friendly technology.

Further the Municipality cooperates with Universities, Technological Institutes, environmental associations, non-governmental organizations, energy producing companies, Municipal Enterprises with high energy consumption rates, third-sector private companies, transportation enterprises and outermost citizens, whose sensitization and attitude change, towards adoption of good practices, is essential pre-requisite in the achieving sustainable energy conscience. Apart from the previously mentioned benefits this whole process as described above will also be indicative for the European Commission in order to communicate directives for the methodology in energy consumption and certification of best practices (e.g. Energy Certificates) for public buildings and the creation of financial tools in the energy sector.

\section{A. Actions and projects}

Within the framework of fulfilling its obligations arising from its membership in the "Covenant of Mayors", the Municipality of Hersonissos since 2011:

- submitted 15 months after its accession the "Action Plan for Sustainable Energy" (APSE)

- submitted the first two-year progress report on evaluation (being one of the seven Greek municipalities that completed this stage)

- organized "Energy Days" in cooperation with the Energy Agency of Crete

- carried out awareness campaigns for citizens in sustainable energy issues and environmental protection in general

- submitted proposals not only for improving the energy efficiency of school buildings (e.g. Episkopi's kindergarten and primary school) but 
also for constructing new ones (e.g. Kopsas kindergarten and primary school) with minimum energy requirements

As diffusing knowledge and awareness is only one task of being a member of the Covenant of Mayors, it is also equally important to move from words to actions. Therefore some of the projects and actions that were implemented by the Municipality of Hersonissos specifically in the public road lighting sector since 2011 are:

- In 2011, the installation of 19 led type lighting with photovoltaic system in one kilometre distance within Anissaras broader area, at a cost of 44,000 euros and funded from own resources.

- In 2012, the Municipality of Hersonissos submitted a proposal to the "Green Fund" to finance the project "Supply LED Lighting for Urban Roads within Hersonissos Municipality" which was approved with a budget of 673,001 euros. Following an open competition auction system, the overall amount for the supply decreased in the amount of $335,745.72$ euros. The commission involved the supply and installation of 51 urban and road luminaires of 48 led lighting (total power per unit $84 \mathrm{~W}$ ) and the supply and installation of 375 urban and road luminaires of 72 led lighting (total capacity per unit $125 \mathrm{~W}$ ). Thus this project resulted in the reduction of carbon dioxide emissions by 298 tons per year in the Municipality's road lighting sector.

- The replacement of bulbs that were not energy efficient in order to save energy and increase the quality of public lighting. The budget for this action was 25,080 euros in a two-year period 2013 and 2014.

- In 2015 the construction of a project by the title "Lighting the coastal road of Stalis", where the old luminaries were replaced by led lighting of total capacity per unit $81 \mathrm{~W}$, to a length of $1.8 \mathrm{Km}$ at a cost of 395,000 euros.

- In 2016 the amount of $150,000 €$ was committed by the annual budget for replacing the old street lamps (sodium or mercury vapour lamps) with adequate based on the street category led lights.

- Last but not least in 2015 - 2016 an investigation was conducted by a third party in relation to the Municipality's funding capacity with a loan by the Greek Deposits and Loans Fund, for a complete and massive lighting project which will replace the majority of road lighting conventional luminaries with led luminaires for the illumination of not only the coastal front $(40 \mathrm{Km})$ but also its hinterland. The amount of the loan was estimated to the amount of 4.7 million euros.

Nonetheless new projects are constantly added in the municipality's development planning as different auctions or funding opportunities allow the materialization of energy saving projects in the field of road lighting. It is important at this point to highlight the obstacles that local authorities have to deal with in order to achieve strategic goals. The first and most significant is the lack of financial resources as the insurance of adequate funding is often 
compromised by necessity. Hence the financial means that local authorities can use for this purpose are mainly either National or European funds, and in fewer cases their own resources. In the case of the Municipality of Hersonissos some of the financial tools that were used for achieving its objectives were and are the Green Fund; ESPA; Horizon 2020; the European cross-border cooperation programs etc. In addition, the possibility of public-private partnership (PPP) for energy saving projects in Hersonissos Municipality is explored.

Having ensured the financial means, local authorities have to face another obstacle in materializing energy saving projects in road lighting; the constantly changing timetable for submitting proposals in the central government along with the bureaucracy involved in implementing the ones already accepted for financing.

\section{The public road lighting project}

According to international studies up to $40 \%$ of the electricity consumption of a municipality comes from the street lighting network. Furthermore the operation of the road network has an environmental cost, which translates to high $\mathrm{CO} 2$ emissions - 0.3987 Kgr / KWh -, heat dissipation of the same luminaires and contamination of the environment with heavy metals during the deposition of the lamps at the collection sites. Thereupon one of the areas in which the Municipality referred to in the Covenant of Mayors was the public road lighting. In this area the emissions of carbon dioxide were calculated with base year 2010 and measurable and demonstration actions were determined aiming to reduce pollutants by 2020 . Hence within the Municipality of Hersonissos there is a grid of 290 electrical power registering meters referring to a network of streets and public squares with an annual consumption of 2,681 MWh, in 2010 [8]. At European level the annual consumption for public lighting in Europe is between 40 and $80 \mathrm{KWh}$ per capita, which is lower than that consumed in the Municipality. It should be taken however under consideration the fact that the Municipality of Hersonissos hosts a large number of people (approximately 25,000 ) who work seasonally (for seven months per year) in the tourism industry along with six million overnight stays during the holiday season. 
Table 2. Lamp distribution of municipal road lighting [8]

\begin{tabular}{|l|c|c|c|c|c|c|}
\hline $\begin{array}{c}\text { Type of } \\
\text { lamps }\end{array}$ & Watt & Lm & $\begin{array}{c}\text { Total } \\
\text { Watt }\end{array}$ & $\begin{array}{c}\text { Lm/ } \\
\text { Watt }\end{array}$ & $\begin{array}{c}\text { Number of } \\
\text { lamps }\end{array}$ & $\begin{array}{c}\text { Consumption } \\
\text { (KWh/day })\end{array}$ \\
\hline Hg & 125 & 6300 & 137 & 50 & 1764 & 2658 \\
\hline Hg & 250 & $\begin{array}{c}1300 \\
0\end{array}$ & 271 & 52 & 269 & 802 \\
\hline MHHP & 70 & 5500 & 80 & 79 & 152 & 134 \\
\hline CFL & 20 & 1200 & 24 & 60 & 935 & 247 \\
\hline NA & 150 & $\begin{array}{c}1700 \\
0\end{array}$ & 172 & 113 & 152 & 288 \\
\hline NA & 250 & $\begin{array}{c}3300 \\
0\end{array}$ & 276 & 132 & 1100 & 3340 \\
\hline NA & 400 & $\begin{array}{c}5550 \\
0\end{array}$ & 434 & 139 & 450 & 2148 \\
\hline
\end{tabular}

Table 2 shows the distribution in the number and types of lamps of municipal's road lighting based on the data gathered from one third of the overall street lighting network for the creation of the Action Plan for Sustainable Energy in 2011. Thus 2,976 MWh/year was the total consumption for road lighting in 2011 responding to 3,419 tCO2 emissions. However recent data (field records in 2016) shows that a total number of almost 12,000 lamps constitute the main road lighting network.

In the Action Plan for the Sustainable Energy Forum the Municipality programmed energy saving projects within road lighting in order to reduce pollutant carbon dioxide emissions by $72.97 \%$ till 2020 . These projects were either demonstratively or invasive. The demonstration projects were small-scale projects where the reduction of energy consumption had not significant numerical impact, but could be works-standard for the residents of the region. Invasive projects were those that were mainly calculated on pollutant reduction measurements of carbon dioxide and were large-scale projects with significant budget. 
Table 3. Invasive projects [8]

\begin{tabular}{|l|c|c|}
\hline \multicolumn{1}{|c|}{ Project } & $\begin{array}{c}\text { Result } \\
(\%)\end{array}$ & $\begin{array}{c}\text { Total reduction } \\
(\mathbf{t} / \mathbf{y e a r})\end{array}$ \\
\hline $\begin{array}{l}\text { Interventions energy savings with replacement of } \\
\text { luminaires / lamps in 2013 }\end{array}$ & 8.7 & 298 \\
\hline Removal of duplication networks & 10 & 342 \\
\hline $\begin{array}{l}\text { Interventions energy savings with replacement of } \\
\text { luminaires / lamps in 2016 }\end{array}$ & 53 & 1,772 \\
\hline Dimming application for power reduction & 1.1 & 39 \\
\hline $\begin{array}{l}\text { Replacement of luminaries with autonomously } \\
\text { photovoltaic }\end{array}$ & 1.3 & 44 \\
\hline & SUM & 2,495 \\
\hline
\end{tabular}

According to 2014 biannual report [9] the implementation of initiatives towards reducing the carbon footprint concerning public road lighting led to a reduction of $8.71 \%(3,121 \mathrm{tCO} 2$ /year). These projects nonetheless had also a social impact as:

- The new led lights increased the streets' brightness not only due to their ability to maintain their brightness for a longer period (the old lamps presented a $60 \%$ reduction of their brightness over time) but also because led lights restrain their light vertically (the light from old luminaries was diffused in all directions and thus only 50\% of the generated light was actually utilized).

- The replacement of old luminaries with new technology ones reduced their downtime minimizing thus the percentage of the network that stays out of order daily (based on empirical data it is estimated that 15\% of Municipality's road lighting network is in a daily base out of order).

Consequently and based on the daily interaction of Municipality's Technical Service with the citizens (and according to their statements) the improvement of street lighting, by replacing the old lamps with higher quality's luminaries, increased their sense of security and therefore improved their quality of life as they could move around easier during night.

\section{Conclusion}

Energy being a cross-cutting issue, the effect on multilevel governance and networking at European level is essential for strengthening the effectiveness of the battle against climate change. As the energy challenge is multitasked, international cooperation and networking with strategic partner countries will support local and regional authorities in achieving their objectives and contribute to the global efforts to mitigate climate change and reduce $\mathrm{CO} 2$ emissions [10]. Hence local authorities must take the lead in action and set a good example, not only because they are closer to citizens, but also because they can become the 
mean for transforming the cities and making them more attractive and sustainable for both citizens and visitors.

The Municipality of Hersonissos joined the "Covenant of Mayors" in April 2011, targeting the improvement of both its citizens' quality of life and in the same time its environment. As an active member of the initiative the Municipality has submitted not only an APSE but also a biannual report in 2014 . By creating the ground floor and with the constant monitoring of energy consumption and emissions of carbon dioxide data, at local level, the Municipality is not only ready to submit the next biannual report by the end of 2016 but has also the knowledge and the experience to take political decisions and to apply corrective movements with ultimate goal to protect the environment and to maintain a positive result in the battle against climate change [8]. By staying committed to its goals for energy saving the Municipality of Hersonissos contributes to the economic, environmental and social development and prosperity not only of the inhabitants of today but also for future generations. Thus the implemented actions and projects throughout its region these last five years, led not only to the reduction of energy consumption and carbon dioxide emissions but also increased the sense of security, decrease delinquent behaviour and criminal low-level operations in areas where the lighting system was not sufficient.

This article highlights that significant potential for energy savings from road lighting can be reaped in each phase of the local authority energy renovation process: planning, implementing and monitoring. The need therefore for public authorities to raise awareness and build skills on energy related issues not only among civil servants, but also among citizens is essential. Even though the Municipality of Hersonissos has taken actions to reduce its energy footprint, much more remain to be done. Financial and bureaucratic obstacles have to be overcome and in order for local authorities to remain active and resourceful central government have to extend a helpful hand and citizens have to support the municipalities' efforts with their positive interaction.

\section{References}

[1] http://www.eumayors.eu/index_en.html

[2] Thissen M., Frank Van Oort, Diodato D., Ruijs A., "Regional competitiveness and smart specialization in Europe: Place-based development in international economic networks", Edward Elgar Publishing Limited, Cheltenham, UK, 2013

[3] Commission staff working document: Lisbon strategy evaluation document, Brussels, 2.2.2010

[4] Katsios S.,"The shadow economy and corruption in Greece", South- Eastern Europe Journal of Economics, 1, pp. 61-80, 2006 
[5] Maroulis N., Mikroglou E., "Erawatch: country reports 2011: Greece", European Commission, 2011

[6] Yfanti S. "An investigation of Critical Success Factors for the creation of clusters within micro companies working in the construction sector", $\mathrm{PhD}$ thesis in Glasgow Caledonian University,2015

[7] Hellenic Statistical Authority, http://www.statistics.gr/el/statistics//publication/ SAM03/-

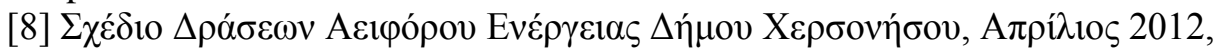
Action Plan for Sustainable Energy, April 2012, (in [language])

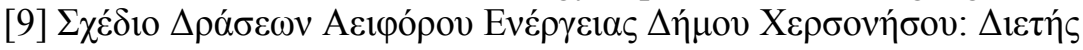
Avapopó, 1.11.2014, Action Plan for Sustainable Energy: Biannual report, 1.11.2014, (in [language])

[10] Horizon 2020 Work Programme, "Secure, Clean and Efficient Energy", European Commission Decision C (2015) 6776 of 13 October 2015 